\title{
THE ROLE OF CORPORATE VALUES TO CORPORATE SOCIAL RESPONSIBILITY AND DIVIDEND POLICIES THAT AFFECT STOCK RETURNS
}

\author{
Noviyah Nyi Mas Rizki \\ ABFI Perbanas Institute, Indonesia \\ E-mail: nyimas.rizki@perbanas.id
}

\begin{abstract}
The purpose of this study is to analyze whether firm value mediates the effect of Corporate Social Responsibility (CSR) and dividend yield on stock returns. The samples are 12 companies; they chosen by purposive sampling method. The data is processed by panel regression and Sobel Test using eViews 9.0. The results showed that firm value is mediating the effect of Corporate Social Responsibility (CSR) to stock return. The second result is firm value isn't mediating the effect of Dividend Yield to stock return.
\end{abstract}

\section{KEY WORDS}

Corporate social responsibility, dividend yield, firm value, stock return.

One of the goals of a company is to prosper the shareholders. Shareholders have believed to invest their money in a company and hoping that their investment will grow in a certain time. The company must run the operational activities well, so the company can generate profits and realize the expectations of shareholders. In running its operational activities the company also has several obligations, one of which is carrying out CSR (Corporate Social Responsibility) activities. The obligation has been regulated by the government in UU RI No.40 of 2007 Pasal 74 about Limited Liability Company, that is, the company that carries out its business activities in and / or related to natural resources must carry out Social and Environmental Responsibility, if it does not carry out the obligations referred to will be subject to sanctions in accordance with the provisions of the legislation.

According to Chen and Lee (2017) there is a positive influence between CSR and financial performance of a company. If the company has better CSR activities, the better reputation of a company and will get support from the government. As a result, the company's financial performance will increase which will also affect profits and have a positive influence on the welfare of shareholders.

Investors will be satisfied with the payment of dividends received each period. The amount of dividend payment can be viewed positively or negatively by investors. If dividend payment is too large, then the assumption of retained earnings held by the company in that period is a little so that the capital to develop its business is reduced, and has a negative impact from the investor's perspective. Conversely, if the dividend amount and frequency are very small, the welfare of investors will decrease.

Stock returns received by investors not only from dividends, but also from capital gains. According to Tax Differential Theory presented by Litzenberger and Ramaswamy stated that investors prefer capital gains rather than dividends, even though the company decides to distribute dividends, investors tend to choose dividend payments in small amounts so that the retained earnings remain to develop larger businesses.

CSR and dividend payments made by the company will affect the value of the company which will also affect stock price movements, and affect the stock returns received by investors. In this research, we want to examine how the effect of CSR and dividends is the costs that must be spent by the company on the value of the company that has a role in influencing stock returns. 


\section{THEORETICAL REVIEW}

In this research, there are four variables, CSR and Dividend Yield are independent variables, company value is a mediating variable, and stock return is the dependent variable. The following is the framework of this research:

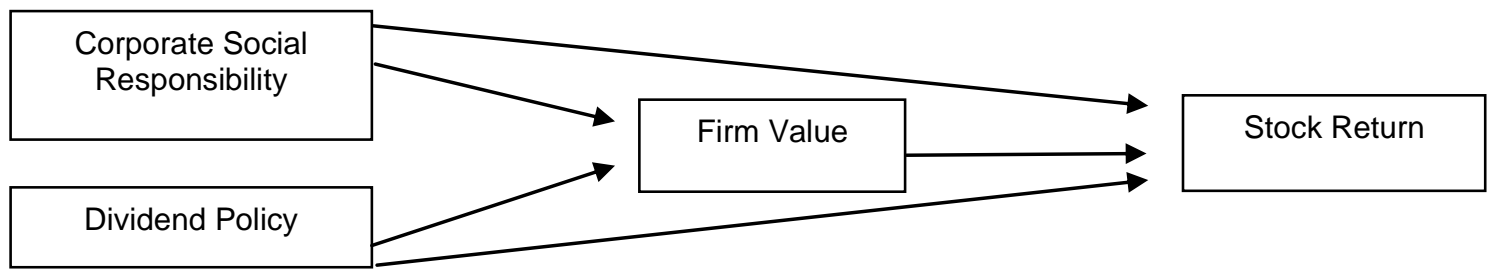

Figure 1 - Corporate Social Responsibility (CSR)

Corporate CSR is expected to provide long-term benefits, positive relationships with stakeholders must be maintained to minimize conflicts that will occur (Gitman \& Zutter, 2015). According to Lins, et al (2017) with companies implementing CSR activities that are beneficial to the environment can increase investor confidence in the company, the company's image will look better in the eyes of the public and will produce something positive. At present the responsibility of the company must rest on the triple bottom lines, namely corporate responsibility on social, environmental and financial aspects so that each company is required to disclose information about corporate social responsibility or Corporate Social Responsibility (Hartoyo, 2016). To measure the Corporate Social Responsibility Index used categories derived from the GRI (Global Reporting Initiative) indicator.

$$
\operatorname{CSRDI} I_{J}=\frac{\sum X_{i j}}{n_{j}}
$$

Dividend Yield. Investors want a relatively stable dividend distribution because it reduces uncertainty about the expected results of investments made and can also increase investor confidence in the company so that the value of shares also increases. Dividend yield is one indicator that is often used by securities analysis to measure the performance of a company in distributing profits on income of shares traded in the capital market. The yield dividend in this study can be formulated as follows:

$$
\text { Dividend Yield }=\frac{\text { Dividend Per Lembar Saham }}{\text { Harga Saham Per Lembar Saham }} \times 100 \%
$$

Company Value. To measure the value of a company in this study, Tobin's $Q$ method is used as a valuation ratio (Valuation Ratio), which is the most comprehensive measure to assess the work of a company, because the ratio reflects a combination of risk-ratio effects and return-yield ratios. If the value of Tobin's $Q$ is more than one company, this will stimulate investment, whereas if the value of Tobin's $Q$ is less than one, it will reduce investment. Tobins' $Q$ calculations are as follows:

$$
\text { Tobin's } Q=\frac{\text { Market Value of Equity }+ \text { Book Value of Debt }}{\text { Book Value of Total Asset }}
$$

Stock Return. Based on the two concepts by Tandelilin (2011), the total return of an investment can be calculated by using yield and capital gains obtained from an investment. In this study, the researcher calculates stock returns by using actual return, which is the difference between the current stock price and the stock price in the previous period or can be formulated as follows: 


$$
\mathrm{R}_{\mathrm{it}}=\frac{P t-\left(P_{t-1}\right)}{P_{t-1}}
$$

Where: $R_{i t}=$ Stock return in the $t$ period; $P_{t}=$ Stock price in $t$ period; $P_{t-1}=$ stock price before $t$ period.

\section{METHODS OF RESEARCH}

The population in this research includes listing companies on the Indonesia Stock Exchange (IDX) during the 2012-2016. The sampling method used by the author in this research was using purposive sampling method. Samples taken from populations that have met the criteria there are 12 companies. This research will use panel data regression because the data consists of time series and cross section.

In estimating panel data regression there are three models, namely Common Effect (CE), Fixed Effect (FE), and Random Effect (RE). To choose the best model, Chow test, Huasman test, and Lagrange test were conducted. In addition to conducting panel data regression, in this study a Sobel test was conducted to determine whether the company value variable mediates the effect of CSR variables and yield dividends on stock returns. The first step is by calculating the indirect coefficient value, after that it looks for the standard error value from the indirect effect coefficient.

$$
\begin{gathered}
S p 2 p 3=\sqrt{p 3^{2} S p 2^{2}+p 2^{2} S p 3^{2}+S p 2^{2} S p 3^{2}} \\
t \text { hitung }=\frac{p 2 \times p 3}{S p 2 p 3}
\end{gathered}
$$

If the result of $t$ count is greater than $t$ table with a 0.05 level of significance, it can be concluded that the mediation coefficient is significant which means that the mediating variable influences the influence of the independent variable on the dependent variable.

\section{RESULTS AND DISCUSSION}

To prove the first hypothesis is whether the company value variable mediates the effect of CSR on stock returns, regression and Sobel Test are carried out with the following results:

Table 1 - Results of Multiple Regression CSR and Company Value - Stock Returns

\begin{tabular}{|c|c|c|c|}
\hline Dependent Variable & Company Value & \multicolumn{2}{|c|}{ Stock Returns } \\
\hline Model & Random Effect & \multicolumn{2}{|c|}{ Fixed Effect } \\
\hline Independent Variable & CSR & CSR & Company Value \\
\hline Coefficient & 0.005095 & -0.507319 & 92.72008 \\
\hline Standard Error & 0.001770 & 0.416999 & 31.49466 \\
\hline t Statistics & 2.878643 & -1.216594 & 2.943993 \\
\hline Probability & 0.0056 & 0.2300 & 0.0051 \\
\hline
\end{tabular}

Source: Eviews 9.0.

Standard error from the indirect effect coefficient:

$$
S p 2 P 3=\sqrt{P 3^{2} S p 2^{2}+P 2^{2} S p 3^{2}+S p 2^{2} S p 3^{2}}=0.236
$$

The t-statistics value of the influence of mediation:

$$
t=\frac{p 2 \times p 3}{S p 2 p 3}=\frac{0.005095 \times 92,72008}{0.236}=2.0017
$$


Because the value of t count of 2.0017 is greater than the value of t table of 1.67155 , then there is a mediating effect of the company value variable in the effect of CSR on stock return. CSR variables directly do not affect stock returns, but indirectly CSR influences stock returns by mediating firm value variables. CSR has a significant positive effect on company value. The greater the CSR activities carried out by the company, the better the company's reputation in the eyes of the public and investors. This causes an increase in the value of the company. The results of this study support the results of Chen \& Lee (2017) research, namely that the higher the company invests in the form of CSR will increase institutional shareholders, and develop the size of the company which results in the growth of profits and increasing corporate value. The value of the company has a significant positive effect on stock returns, the higher the value of the company, the higher the investors value the company so that investors want to buy shares at a higher price. So the increasing value of the company will cause an increase in stock returns. This result is different from the results of the research from McMillan (2017), which is that firm value has a significant negative effect on stock returns and Rahman \& Mustafa (2018) states that firm value does not significantly influence stock returns.

Next, to prove the second hypothesis is whether the company value variable mediates the effect of the Dividend Yield on stock returns, Sobel Test is carried out with the following results:

Table 2 - Results of Multiple Regression Dividend Yield and Company Value - Stock Returns

\begin{tabular}{|c|c|c|c|}
\hline Dependent Variable & Company Value & \multicolumn{2}{|c|}{ Stock Returns } \\
\hline Model & Random Effect & Fixed Effect \\
\hline Independent Variable & Dividend Yield & Dividend Yield & Company Value \\
\hline Coefficient & -0.012215 & -3.874680 & 66.78055 \\
\hline Standard Error & 0.005714 & 1.234687 & 27.00367 \\
\hline t Statistics & -2.137587 & -3.138189 & 2.473017 \\
\hline Probability & 0.0368 & 0.0030 & 0.0172 \\
\hline
\end{tabular}

Source: Eviews 9.0.

Standard error from the indirect effect coefficient:

$$
S p 2 P 3=\sqrt{P 3^{2} S p 2^{2}+P 2^{2} S p 3^{2}+S p 2^{2} S p 3^{2}}=27.008
$$

The t-statistics value of the influence of mediation:

$$
t=\frac{P 2 \times P 3}{S p 2 p 3}=\frac{0.012215 \times 66.78055}{27.008}=0.0303
$$

Because the value of $t$ count of 0.0303 is smaller than the value of $t$ table of 1.67155 , then there is no mediating effect of the company value variable in the effect of the Dividend Yield on stock returns.

\section{CONCLUSION AND RECOMMENDATIONS}

The value of the company mediates the effect of CSR on stock returns. CSR variables directly do not affect stock returns, but indirectly CSR influences stock returns by mediating firm value variables. CSR has a significant positive effect on company value. Dividend yield directly affects stock returns, and firm value does not mediate the effect of dividend yield on stock returns. Dividend yield has a significant negative effect on stock returns. From the results of this study, the authors recommend to the issuers to pay attention to the activities of CSR and dividends which are costs for the company because it affects stock returns. 


\section{REFERENCES}

1. Aggarwal \& Schloetzer. 2016. Do Corporate Governance Mandates Impact Long Term Fim Value and Governance Culture? Journal of Corporate Finance. United States: Elsevier.

2. Agus Widarjono. 2013. Ekonometrika: Pengantar and aplikasinya, Ekonosia, Jakarta.

3. Agustina, Wahyuni, dkk. 2015. Pengaruh Intellectual Capital,Corporate Social Responsibility, and Good Corporate Governance Terhadap Kinerja Keuangan (Studi Kasus Pada Perusahaan BUMN yang Terdaftar di Bursa Efek Indonesia Pada Tahun 2011-2013). e-Journal S1 Ak Universitas Pendidikan Ganesha Jurusan Akuntansi Program S1( Vol. 3 No. 1 Tahun 2015).

4. Alexander, Nico and Nicken Destriana. 2013. "Pengaruh Kinerja Terhadap Return Saham". Jurnal Bisnis and Akuntansi Vol.15, No.2, Desember 2013:123-132 ISSN:14109875.

5. Ammann \& Oesch. 2010. Corporate governance and firm value: International evidence. Journal of Empirical Finance. Elsevier.

6. Ardianto, E. \& Machfudz, D. (2011). Efek kedermawanan pebisnis and CSR. Jakarta: PT Elex Media Komputindo.

7. Arslan, Muhammad and Rashid Zaman. 2014. "Impact Of Dividend Yield And Price Earning Ratio On Stock Returns:A Study Non-Financial Listed Firms Of Pakistan Stock Exchange". Research Journal of Finance and Accounting. Vol.5, No.19,2014 ISSN:22221697(paper) ISSN:2222-2847 (online).

8. Bidhari, Sandhika Cipta, dkk. 2013. Effect of CSR information Disclosure on Financial Performance and Firm Value in Banking Industry Listed at Indonesia Stock Exchange. European Journal of Business and Management, ISSN 2222-1905, Vol.5, No. 19.

9. Budiasih, I Gusti Ayu Nyoman. 2015. Intellectual Capital and Corporate Social Responsibility Pengaruhnya Pada Profitabilitas Perbankan. Jurnal Dinamika Akuntansi Vol.7, No.1, Maret 2015, pp. 75-84.

10. Brigham, Eugene F. and Houston, Joel F. 2012. Dasar - Dasar Manajemen Keuangan. Edisi ke - 11. Penerjemah Ali Akbar Yulianto, Jakarta: Salemba Empat.

11. Chen \& Hung, 2017. Does Corporate Value Affevt the Relationship Between CSR and Stock Returns? Journal of Sustainable Finance and Investement. United Kingdom: Taylor \& Francis Group.

12. Crisostomo \& Freire. 2011. CSR, Firm Value, and Financial Performance in Brazil. Social Responsibility Journal Vol. 7 No. 2 Pages 295 - 309. Emerald Group Publishing.

13. Edi Suharto, Pekerjaan Sosial di Dunia Industri, Memperkuat CSR, (Bandung: CV. Alfabeta, 2009), hal. 105.

14. Fahmi, Irham. 2014. Analisis Kinerja Keuangan Panduan Bagi Akademisi, Manajer, and Investor Untuk Menilai and Menganalisis Bisnis Dari Aspek Keuangan. Bandung: Alfabeta.

15. Gherghina \& Vintila. 2014. An Empirical Research on the Relationship Between Corporate Social Responsibility Ratings and U.S. Listed Companies' Value. Journal of Economics Studies and Research. IBIMA Publishing.

16. Gul. 2002. "Growth Opportunities, Capital Structure, and Dividend Policies of Japan Firms: Some Further Contracting Cost Evidence". SSRN`s Journals 2002.

17. Gitman, Lawrence J and Zutter, Chad J. 2012 Principle of Managerial Finance 13th edition. Pearson.

18. Hadi, Nor. 2014. Corporate Social Responsibility. Yogyakarta: Graha Ilmu.

19. Hassanein \& Hussainey. 2015. Is Forward Looking Financial Disclosure Really Informative: Evidence from UK Narrative Statements. International Review of Financial Analysis. United Kingdom: Elsevier.

20. Horne, James C. Van and John M. Wachowicz Junior. 2007. Fundamental of Financial Management, 12th ed. Penerjemah Dewi Fitriasari, M.Si. and Deny Arnos Kwary, M.Hum. Jakarta: Salemba Empat, 2007 ISBN-10: 979-691-264-3. 
21. Hirt, Block, 2006, Fundamentals of Investment Management, 8th Edition, McGraw International Edition.

22. Husnan, Saud and Eny Pudjiastuti. 2002, Dasar-dasar Manajemen Keuangan. Yogyakarta: AMP YKPN.

23. Iskandar, Alwi Z. 2003. Pasar Modal Teori and Aplikasi, Edisi Pertama. Jakarta: Penerbit Yayasan Pancur Siwah.

24. Jogiyanto. 2013. Teori Portofolio and Analisis Investasi. Edisi Kedelapan. Yogyakarta: BPFE.

25. Kasmir. 2014. Analisis Laporan Keuangan. Jakarta: PT Raja Grafindo Persada.

26. Kurniasih, Ninik and Susan Andriana. 2011."Pengaruh Dividend Yield and Price Earning Ratio Terhadap Return Saham Pada Level Investment Opportunity Set (IOS) Yang Berbeda". Jurnal Eksos, Vol. 7, No.1, 38-45 ISSN:1693-9093.

27. Lee \& Chen. 2017. The Influence of CSR on Firm Value: An Application of Panel Smooth Transition regression on Taiwan. Apllied Economics Vol.49 No.34 pages 3422-3434. Tiwan: Routledge.

28. Ningsih, Vivi Seftya, Halim Abdul, Wulandari Retno. 2016. "Pengaruh Price Earning Ratio, Dividend Yield, Book To Market Ratio and Audit Quality Terhadap Return Saham". Journal Riset Mahasiswa Akuntasi (JRMA).

29. Putra, Yogie Rahmanda and Mimin Widyaningsih. 2016. "Pengauh Laba Akuntansi, Komponen Arus Kas, and Dividend Yield Terhadap Return Saham (Studi Pada Perusahaan Sektor Pertambangan di Bursa Efek Indonesia Periode 2012-2014)". Jurnal Riset Akuntasi \& Keuangan Vol. 4, No. 2, 2016, pp:108-120 ISSN:2541-061x (elektronik) ISSN:2338-01507 (cetak).

30. Saunders, Anthony and Marcia Millon Cornett, 2008. Financial markets and institutions 4th Edition. McGraw-Hill Irwin ISBN:978-0-07-018756-6.

31. Samsul, Muhammad. 2006. Pasar Modal and Manajemen Portofolio. Surabaya: Erlangga

32. Sawir, Agnes. 2005. Analisis Kinerja Keuangan and Perencanaan Keuangan Perusahaan. Jakarta: PT. Gramedia Pustaka Utama.

33. Sudiyatno, Bambang. Puspitasari, Elen. 2010. Tobin's Q and Altman Z-Score Sebagai Indikator Pengukuran Kinerja Perusahaan. Kajian Akuntansi. Pebruari 2010, Hal. 9-21.

34. Sutrisno, 2003, Manajemen Keuangan (Teori, Konsep, and Aplikasi), Edisi Pertama, Cetakan Kedua. Yogyakarta: EKONISIA.

35. Symitsi \& Stamolampros. 2017. Employee's Onlinen Reviews and Equity Prices. Economics Letters. United Kingdom: Elsevier.

36. Tambunan, Andy Porman and Edhi S. Widjojo, MBA., CFA. 2007. "menilai harga wajar saham (stock valuation)". Penerbit PT. Elex Media Komputindo, Kelompok Gramedia Jakarta EMK 237070501 ISBN 978-979-27-0308-5.

37. Tandelilin, Eduardus. 2011. "Analisis Investasi and Manajemen Portofolio". Edisi Pertama: BPFE.

38. Timbate \& Park. 2018. CSR Performance, Financial Reporting, and Investors Perception on Financial Reporting. Sustainability. Korea: MDPI.

39. Undang-Undang Republik Indonesia No. 40/2007 tentang Perseroan Terbatas (UU PT) pasal 74.

40. Viscano \& Chuusa. 2015. Analyzing the Influence of The Funds Support on Tobins $Q$ Using SEM and fzQCA. Journal of Business Research. United Kingdom: Elsevier.

41. Walker \& Zhang. 2018. The Mirror Effect: Corporate Social Responsibility, Corporate Social Irresponsibility and Firm Performance in Coordinated Market Economies and Liberal Market Economies. British Journal of Management, Vol. 0, 1-18 (2018). British Academy of Management.

42. Widyastuti, Umi and Ati Sumiati. 2015. MSI. "Dasar Dasar Manajemen Keuangan" Editor Dr. Saparuddin Muchtar, Diterbitkan Oleh Lembaga Pengembangan Pendidikan UNJ ISBN 978-602-72120-9-1. 